\title{
ドイツの都市景観における建築物色彩の印象評価に関する研究 STUDY ON EVALUATION OF IMPRESSION ABOUT COLOR IN BUILT ENVIRONMENT IN GERMANY
}

\author{
市田圭*
}

Kei ICHIDA

\begin{abstract}
This study focuses on color in built environment in Germany and evaluation of impression about it. Urban landscape in Germany is generally famous for its beauty in visual. Especially, color of buildings is the influential factor of that. Colorscape in Germany is characteristic in that it is mainly constructed by colors of natural materials and also some vivid or bright colors can be seen. We can say that there is strong relationship between human aesthetic to urban landscape and those characteristic colors.

The purpose of this study is to reveal subjects' evaluation of impression about colorscape in Germany. For this purpose, this study especially focuses on subjects' image about colorscape, in addition to the analysis of evaluation of impression.

This study consists of two researches: (1) research on image of colorscape, and (2) research on evaluation of impression about colorscape. From the research (1), the patterns of subjects' image about colorscape in Germany are revealed. They are following two: (i ) colors of natural materials, and (ii) vivid, bright colors and its variety. And from the research (2), the details of subjects' evaluation of impression about colorscape in Germany are revealed. They are following three: ( i ) unity of colors, (ii) colors of natural materials, and (iii) partly emerged vivid, bright colors. The subjects' aesthetic to colorscape in Germany can be explained by those factors.
\end{abstract}

Keywords : Germany, urban landscape, color, colorscape, evaluation of impression, image ドイツ, 都市景観, 色彩, 色彩景観, 印象評価, イメージ

1.はじめに

\section{1-1. 序論}

都市景観について人々が持つイメージには，実際に都市を訪れた 際に感じるイメージと, 訪れた経験がなくとも想起されるイメージ がある. 前者は都市空間を知覚した経験的なイメージであり, 後者 は雑誌など様々なメディアの情報によって形成される，都市のイメ ージはこれら双方の影響により構築されるため, 両視点から考察さ れる必要がある.

とりわけ，都市のイメージにおいて色彩は重要な影響因子である と考えられる. 住み慣れた日常空間で頻繁に知覚される色彩はもち ろん, 特定の色彩が都市のイメージとして認識される事例もある. こうした都市のイメージに結びつく色彩として, 建築物の色彩は重 要である.それは, 私たちの生活が建造環境を中心に営まれており, それを構成する建築物が日常的に知覚されるためである. 建築物色 彩には，地域の建造環境の特徵に基づく地域性が表象される。 その ため，建築物色彩をめぐる人々のイメージも，そうした地域性を考 慮して研究される必要があると考える.
日本国内で都市の色彩景観が議論され始めたのは 1970 年代以降 であり，それは騒色に代表される建築物色彩の汇濫が問題視された ことによる.色彩は生活空間としての都市を質的に高める要素とし て研究が蓄積されてきた。そのため, 建築物色彩のイメージは都市 の景観計画にも密接に関わる. 地域の環境色彩計画が取り組まれる 今日, 都市の建造環境を特徵付ける諸要素を考慮した建築物色彩の イメージ調査に意義があるといえよう。

\section{1-2. 従来研究}

建築物色彩をはじめ建造環境にみられる色彩を対象とした研究は, 建築学を中心に行われてきた。その中で，建築物色彩による印象評 価を検討した研究を, 方法論の点から 2 種類に分類してまとめる.

まずは，街路景観など特定の景観のモデルを設定し，色彩のシミ

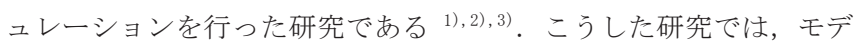
ル化された景観について建築物色彩を変化させることにより印象評 価の差を明らかにしている. 修景操作には, 実地調查における測色 の結果が利用される場合もある。

\footnotetext{
* 名古屋大学大学院環境学研究科 大学院生
}

Graduate Student, Dept. of Geography, Environmental Studies, Nagoya University 
もう一方は, 実際の都市景観, および建築物の画像を用いて修景

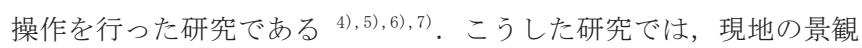
の画像を利用して, 本来の建築物色彩と修景後の色彩による人々の 印象評価の差が分析されている

ここで, 地理学における場所イメージに関する研究 ${ }^{8)}$, 9) に触れる。 こうした研究は, 都市空間における場所について想起されるイメー ジを対象とする. 都市のイメージを構築する象徴要素には, 歴史的 建築物や公園, 文化施設, 産業などがある。人々は, そうした景観 要素をめぐる経験や知識をもとに場所のイメージを持つ. 場所イメ ージは個人により異なるが，集団で共有されると記号化される。さ らに，場所イメージが社会に共通したイメージとして定着すること により記号化が強化される。例えば，絵画に描かれた風景は実際の 場所に対するイメージを増幅させ，新たなイメージを創出する．さ らに, 創出されたイメージは実際の場所イメージとして再構築され 定着する.こうして記号化が強化された場所イメージは, Tuan (1978) 10)で指摘されるように，場所のシンボルへと昇華される.

こうした視点から建造環境の色彩をとらえると, 様々な地域で景 観を特徴づける色彩の記号としての作用がみえる．例えば，建築物 色彩が統一された歷史的景観では, その色彩が場所の象徴要素とな りうる. さらに，色彩は場所のイメージを想起させる媒体として機 能寸る可能性を大いに孕む. それは, 色彩の心理的効果に加え, 人々 が場所を説明する際に共通の知識として利用されやすい一般性によ ると考えられる.このように, 場所イメージの視点から建築物色彩 をみると, 人々が建造環境を知覚し, それによって構築された色彩 をめぐる認識が重要となる. こうした見方も, 色彩景観の印象評価 を分析する際に考慮す心゙きであると考える.

以上より, 研究の課題を以下の 2 点にまとめる. まず, 1 点目は, (1)特定の国や都市の色彩景観の特徵を把握し, その特徵に基づいて イメージ調查を行うことである. それによって, より現実的な都市 の色彩景観について, 被験者の印象評価を分析することが可能にな ると考える. そして, 2 点目は, (2)特定の都市に対して被験者が経 験的に持つイメージを考慮することである. 地理学の研究に示され るように, 場所や色彩景観をめぐる被験者のイメージ, 経験的知識, 先入観を考慮した分析も必要であると考えられる。

\section{2. 研究の目的と方法}

\section{2-1. 研究の目的}

上述の課題をもとに, 本稿では, 色彩景観と人々の美意識との関 係に注目して調查・分析を行う。ここでいう色彩景観とは，建築物 色彩を指寸。本稿の調查・分析では, 色彩景観の地域性を考慮する ことを重視する.

調査・分析の対象とするのは, ドイツの都市景観である. ドイツ では，都市の景観整備が先進的に行われており，都市景観の審美性 が一般的に評価され, 建築物色彩にも統一性や多様性といった地域 性がみられる。そのため, 色彩景観に対する被験者のイメージと印 象評価に注目寸る本稿において有意義な事例であると考えられる.

以上より, 本稿では, ドイツにおける都市の色彩景観に対する被 験者のイメージを明らかにし，それをもとに色彩景観に対する人々 の印象評価を明らかにすることを目的とする.

\section{2-2. 研究の方法}

本稿では，建造環境において視覚的に大きな面積を占める建築物 外壁の色彩を対象とする，具体的な調查内容としては，（i 色彩景 観についてのイメージ調查，（ii）修景操作による画像を用いた印象 評価の調查注 1)を行う。（i ）では，被験者の経験的知識に基づく色 彩景観に対寸る先入観など，色彩景観をめぐるイメージを明らかに することを目標とする，そして，（ii）では，評価項目による調査か らプロフィールによる分析を行い，色彩をめぐる印象評価を明らか にすることを目標とする．

また，ドイツの都市における色彩景観の特徴として以下の 3 点が 指摘されている注 2). その特徴とは, (1)「木材や岩石など建築資材に よる自然基調色注 ${ }^{3)} 」($ 以下, 「自然基調色」)，(2)「色彩の統一感」(以 下，「統一性」)，(3)「高彩度で多色相の色彩」（以下，「鮮やかさ」) の 3 要素である. 従って, 本稿の（i ）および（ii）の調査・分析 も,色彩景観の特徴であるこれら 3 要素に基づいて行うことにする.

\section{3. 色彩景観についてのイメージ調査と印象評価 3-1. 調査の方法}

本稿における調査は, 大学生 77 名（男 20, 女 57）を対象とし, 2005 年 12 月 20 日に行った。被験者は全て日本人であり, ヨーロッ パの都市景観に関する講義の受講者である。調査は，ドイツの都市 の色彩景観に対するイメージと印象評価を把握することを目標とす る。そのため, 被験者には, 調査に用いる画像がドイツの景観であ ることを事前に知らせた。ささらに, 特定の地名から都市景観に無関 係なイメージが連想されることがないよう具体的な都市名は非公開 とし, 後述する調查項目との関係から一般的に有名な建築物および 景観の写真は用いないことにした. よって, 被験者は写真がドイッ の景観であることは知っているが，具体的な都市名は認知していな い. 被験者の大多数はドイツを訪問した経験がない。しかし，被験 者は講義でドイツの景観写真を見た経験があり，ドイツの都市景観 や建築様式についてある程度の知識を持つと考えられる.

調查は, 景観の写真をプロジェクタによってスクリーンに投影し, 質問紙を用いて回答する形式で行った，投影する写真には，本来の ドイツにおける景観の写真 (以下, [本画像]) 6 枚と, それぞれ Adobe Photoshop で建築物色彩を変化させた写真（以下， [修景画像]）の 計 12 枚を使用した。 また, 本稿では［本画像］と［修景画像］によ る印象評価の差に注目する，そのため，調査では 2 枚を並置して投 影する方法を用い，合計 6 組について調査を行った.

調查画像に用いた景観は，都市の地理的位置や規模に偏りがない よう，また複数の都市に共通した形態である都市中心部の「マルク 卜広場」と「商店街（アメニティ・ストリート）」，ドイツに特徴的 な建築様式である「木組み建築」や色彩に特徵がある「新興住宅地」 を網羅できるよう 6 箇所を選定した（図 1) 注 4)。また，本稿は都市 における実際の色彩景観に対する印象評価を重視する立場であり， 画像選定と修景の際にはドイツの色彩景観の特徴を示す 3 要素(「自 然基調色」,「統一性」,「鮮やかさ」）に関する印象評価の変化が把握 できるよう留意した。よって，修景操作では，調査に用いる 6 箇所 の景観のうち, 3 箇所について各 3 要素に関する修景を行い, 残り 3 箇所については 3 要素における 2 要素を組み合わせて修景を行った (図 2，表 1). 


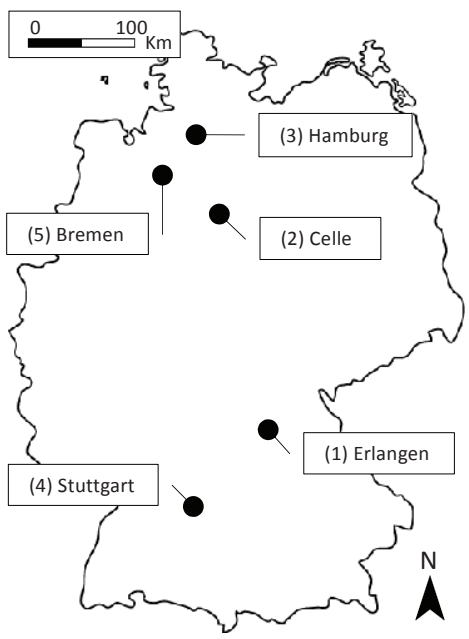

(1) Erlangen (エアランゲン)

(1)新興住宅地 : 都心部に近接した住宅地.

(4)マルクト広場：商業施設が集積した都市中心部.

(2) Celle (ツェレ)

(2)木組夕建築 : 都市中心部の目抜き通りに立地.

(3) Hamburg（ハンブルク）

(3)商店街 : 都市中心部の高級商店街。(ノイアーヴァル)

(4) Stuttgart（シュトゥットガルト）

(5)マルクト広場 : 都市中心部. 近接して市庁舎や教会なと 比較的大規模な建築物が立地。

(5) Bremen（ブレーメン）

(6)商店街 : 商業施設, オフィスビルが集積した都市中心部 のアメニティストリート.

* (1)〜 (6)は図 2 に示す画像の番号を指す.

図 1 調査画像として用いるドイツの都市

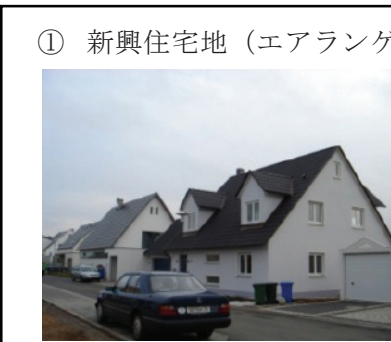

写真 A

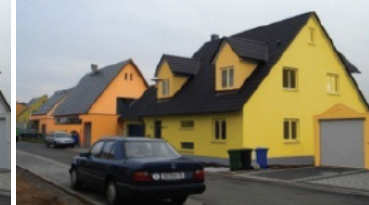

写真 B

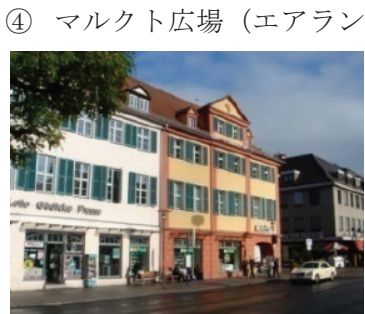

写真 $G$

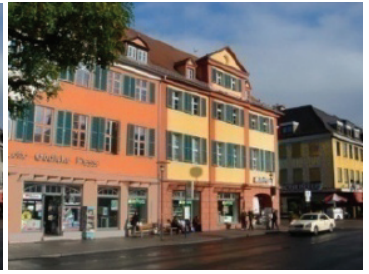

写真 $H$

(2) 木組み建築（ツェレ）

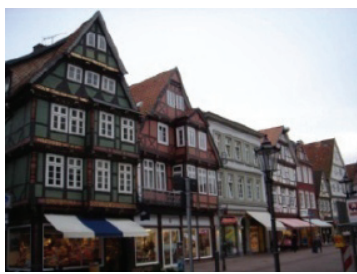

写真 C

(3) 商店街（ハンブルク）

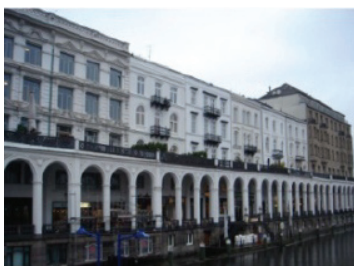

写真 E

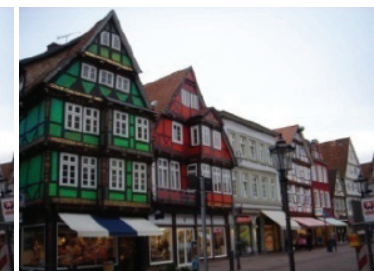

写真 D

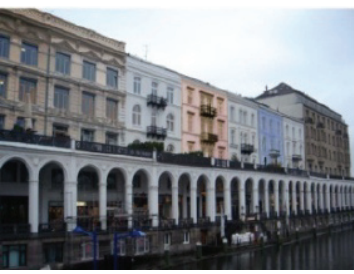

写真 F

(5) マルクト広場（シュトゥットガルト）

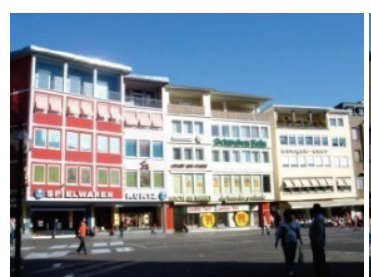

写真 I

(6) 商店街（ブレーメン）

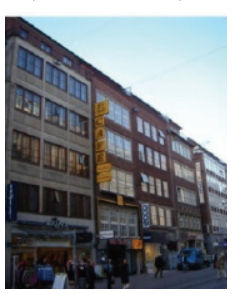

写真 K

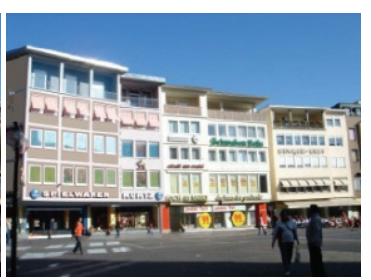

写真 J

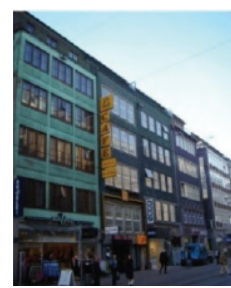

写真 L

* 写真 A, C, E, G, I, K が[本画像], 写真 B, D, F, H, J, L が [修景画像] である.

図 2 調査に用いる [本画像］と［修景画像］

表 1 対象とする都市景観と修景操作の内容

\begin{tabular}{|c|c|c|c|c|c|c|}
\hline \multicolumn{2}{|r|}{ 対象とする景観（都市名） } & & \multicolumn{2}{|r|}{ 修景操作の内容 } & \multicolumn{2}{|c|}{ 変化させた要素 } \\
\hline A & 新興住宅地 (エアランゲン) & $\rightarrow$ & $\mathrm{B}$ & 鮮やかな色彩を加える, 彩度を上げる & (1) & (3) \\
\hline $\mathrm{C}$ & 木組み建築（ツェレ） & $\rightarrow$ & $\mathrm{D}$ & 彩度を上げる（より鮮やかな色彩に変化） & \multicolumn{2}{|c|}{ (3) } \\
\hline E & 商店街 (ハンブルク／ノイアーヴァル) & $\rightarrow$ & $\mathrm{F}$ & 色相をばらつかせる（統一感を下げる） & \multicolumn{2}{|c|}{ (2) } \\
\hline G & マルクト広場 (エアランゲン) & $\rightarrow$ & $\mathrm{H}$ & 鮮やかな色彩による統一感を加える & (2) & (3) \\
\hline $\mathrm{I}$ & マルクト広場（シュトゥットガルト） & $\rightarrow$ & $\mathrm{J}$ & 統一感を上げる, 自然な色彩に変化させる & (1) & (2) \\
\hline K & 商店街（ブレーメン／オベルン通り） & $\rightarrow$ & $\mathrm{L}$ & 人工的な色彩に変化させる & \multicolumn{2}{|c|}{ (1) } \\
\hline
\end{tabular}

(1) =「自然基調色」, (2) =「統一性,$（ 3)=「$ 鮮やかさ」

*1 修景操作は, ドイツの色彩景観の特徴である (1)〜 (3) の要素をもとに行った. 調査では 3 要素に関する印象評価の 変化に注目するため, 修景の方法として各要素を単独, もしくは 2 要素の組み合わせによって変化させた。 


\section{3-2. 質問項目}

(i ) 色彩景観についてのイメージ調查は，3つの質問について, 投影された［本画像］と［修景画像］のうち一方を選択する形式で 行った. 質問は, [質問 I ］：「どちらが本物の景観か」，[質問 II ］：「ど ちらが美しく感じるか」, [質問III]：「どちらに住んでみたいか」で ある.［質問 I ］については，選択した理由についても回答を得た。 また，（ii）修景操作による画像を用いた印象評価の調査では，ド イッの色彩景観の特徴である 3 要素を参考に評価項目として 12 組の 形容詞対を選定した（表 2). 評価項目のうち，(1)〜 (4)は「自然基調 色」，(5)〜8は「統一性」，(9)〜(12)は「鮮やかさ」に関係する. 質問 紙調査では, 各評価項目について 5 段階の評価による回答を求めた。 また，[本画像］と［修景画像］の両方について各々に回答を求め, 計 12 枚の画像について評価項目に関する回答を得た。 なお，調查の 際は［本画像］と［修景画像］が判別しにくいよう，6 組それぞれ について左右をランダムに表示した。 また, 評価項目は複数につい て左右を入れ替え, 順番もランダムに並べ替えて質問紙に記載した.

\section{4. 調査の結果と分析}

4-1. ドイッの色彩景観をめぐるイメージ

4-1-1. 具体的なイメージの内容 - - [質問 I ] より—

表 2 評価項目の一覧

\begin{tabular}{|c|c|c|c|}
\hline \multicolumn{4}{|c|}{ 評価項目（形容詞対） } \\
\hline (1) & 自然な & - & 人工的な \\
\hline (2) & 親しみやすい & - & よそよそしい \\
\hline (3) & ぬくもりのある & - & 泠たい \\
\hline (4) & 歴史的な & - & 現代的な \\
\hline (5) & すっきりとした & - & ごちやごちゃした \\
\hline (6) & まとまりのある & - & ばらばらな \\
\hline (7) & 安定した & - & 不安定な \\
\hline$(8)$ & 変化のない & - & 変化のある \\
\hline (9) & 落ち着きのある & - & 落ち着きのない \\
\hline (10) & 静かな & - & にぎやかな \\
\hline (11) & 刺激のない & - & 刺激的な \\
\hline (12) & くすんだ & - & 華やかな \\
\hline
\end{tabular}

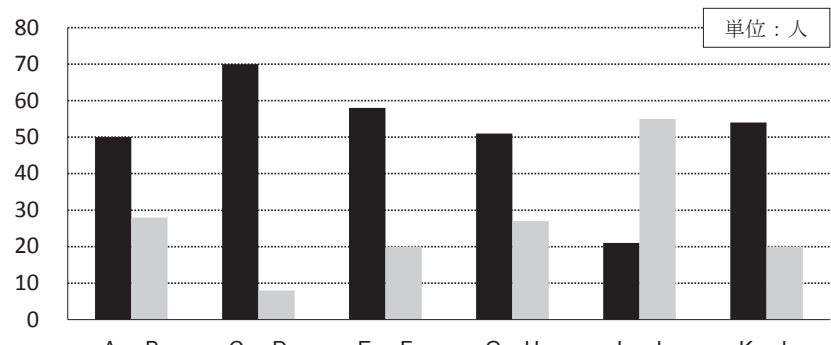

$\begin{array}{lllllllllllll}\text { A } & \text { B } & \text { C } & \text { D } & \text { E } & F & \text { G } & H & \text { I } & \text { J } & \text { K } & \text { L }\end{array}$

\begin{tabular}{l}
\multicolumn{1}{c|}{ ( 理由の解答数 (複数回答可) } \\
\hline \\
\hline
\end{tabular}

図 3 ［質問 I ］に関する調査結果 （i）の調査より，被験者がドイツの都市の色彩景観に対して持つ イメージを分析する.[質問 I ] の調査結果を図 3 に示す.ここでは, 結果から分析される点を以下の 2 点にまとめる.

1 点目は，多数の被験者に共通して確認されたイメージである. これは，写真 $\mathrm{CD} ， \mathrm{EF} ， \mathrm{KL} ， の$ 結果に表れており，[本画像］である 写真 C, F，K，を選択した被験者は大多数が理由として(1)「建物の 色彩が落ち着いているから」, (3)「建物が古い感じがするから」, (5) 「建物の色彩がまとまっているから」を選んでいる。つまり，(1)， (3)，(5)の理由で示された建築物色彩の落ち着きと古さ，統一性がド イツの色彩景観に対する共通したイメージと考えられる.

もう 1 点は，全体の傾向としては目立たないが複数の被験者に共 通して確認されたイメージである。これは，写真 AB，GH，IJの結果 にみられる．まず, 写真 $\mathrm{AB}$ について [本画像］の写真 $\mathrm{A}$ を選択した 被験者のうち 37 名は理由として(1)の色彩の落ち着きを回答してい る.これは 1 点目の共通イメージと一致する結果である。一方，[修 景画像]の写真 B を本来の景観として選んだ被験者のうち 21 名は理 由として(2)「建物の色彩が鮮やかだから」を回答している。これは, 共通イメージとは異なった傾向であり, 回答率の高さからも共有さ れたイメージであるといえる，つまり，共通イメージに加えて，色 彩の鮮やかさに関するイメージも共有されていると考えられる.

こうした傾向は，写真 $\mathrm{GH}$ の結果でも同様にみられる。[本画像] の写真 G を選択した被験者の多数が理由として(1), (5)を回答してい るのに対し, [修景画像]の写真 $\mathrm{H}$ を選んだ被験者のうち約半数は理 由として(2)を回答している.つまり, 色彩景観のイメージとして色彩 の鮮やかさが共有されているといえる. また, 写真 GH の両方に共通 して, 選択した被験者が理由として(5)を回答していることから，色 彩の統一性はドイツの色彩景観に対するイメージを構成する重要な 要素であると考えられる。

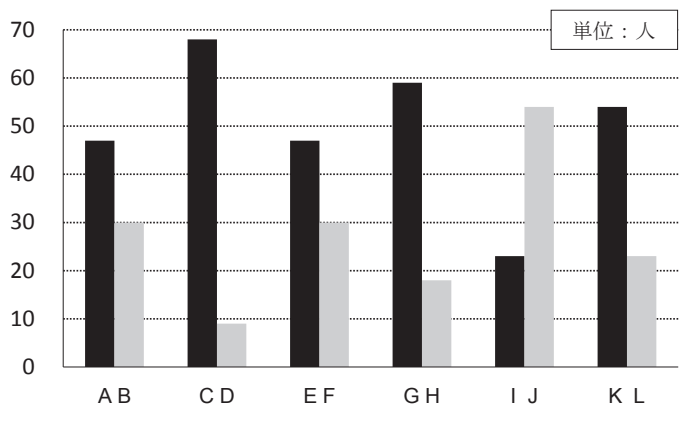

図 4 [質問 II ］に関する調查結果

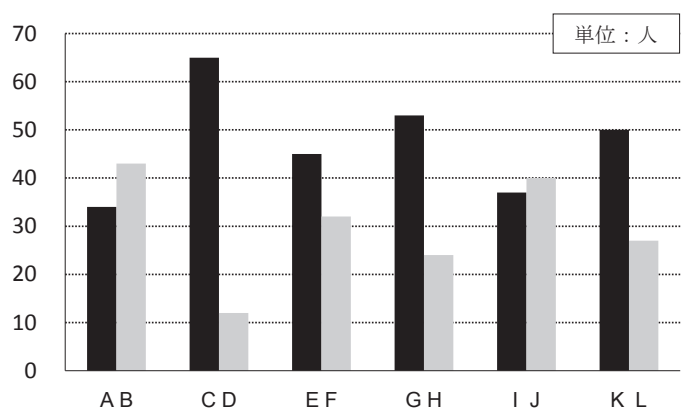

図 5 [質問 III］に関寸る調查結果 
さらに, 写真 IJについても同様である. 写真 IJ は, [本画像]の 写真 I に高彩度の赤色の建築物がみられ, [修景画像] の写真 J は自 然な色味に統一されている点で他の写真の組み合わせとは異なる. 色彩の統一性が高い［修景画像］写真 Jを選んだ被験者は理由とし て(1)と(5)を回答している点で共通イメージに一致する. 同様に, 原 色に近い色彩がみられる [本画像] 写真 I を選択した被験者は, 理 由として(2)を回答している点で色彩の鮮やかさによるイメージを示 すが，同時に(6)「建物の色彩が多様であるから」を答えている点も 注目す心゙きである。つまり, 色彩の鮮やかさと同時に, 色彩的多様 性のイメージも共有されていると考えられる.

以上の結果から，ドイツの色彩景観について［本画像］と［修景 画像を区別する基準には，「色彩の統一性」が共通していることが 分かる. そして, 統一性を判断基準としながら, 色彩的落ち着きや 景観の古さに関するイメージと, 色彩の鮮やかさと多様性のイメー ジの 2 種類が複数の被験者に共有されていることが明らかになった.

つまり, ドイツの都市における色彩景観についてのイメージは,

以下の 2 点により説明される.

（1）色彩の落ち着きと統一性のイメージ

（2）色彩の鮮やかさと多様性, 統一性のイメージ

これら 2 つイメージは, ドイツの色彩景観の特徴として述べた 3 要素に一致する. [修景画像] 写真 $B$, 写真 $\mathrm{H}$ にみられるような暖 色系の明るい色彩は, 実際に伝統的な木組み建築や新興住宅地の建 築物にみられる.よって, 被験者の持つイメージはおおよそ実際の ドイツの都市における色彩景観を反映していると考えられる.

\section{4-1-2. イメージをめぐる認識 一［質問 II］，［質問正］より一}

次に，こうしたイメージをめぐる認識を検討する，本稿は，色彩 景観をめぐる美意識に注目寸るため，ここでは色彩景観をめぐるイ メージが肯定的な認識か，あるいは批判的な認識であるのかに焦点 を当てる.ここでは［質問 II ］および［質問III]の結果（図 4, 図 5) をもとに，2つのイメージの背景にある認識を明らかにする．

表 3 ［質問 II］における写真 B を選択した被験者の回答

\begin{tabular}{c||c|cc|c}
\hline 写真 $\mathrm{AB}$ & \multicolumn{2}{|c|}{$\begin{array}{c}\text { 写真 } \mathrm{GH}, \text { 写真 IJ } \\
\text { (写真 B を選択した被験者の回答) }\end{array}$} & $\begin{array}{c}\text { B を選択した被験 } \\
\text { 者数に占める割合 }\end{array}$ \\
\hline \multirow{2}{*}{ B を選択 } & H・I を選択 & 10 & $(/ 43)$ & $23 \%$ \\
\multirow{2}{*}{$43(/ 77)$} & H を選択 & 3 & $(/ 43)$ & $7 \%$ \\
& I を選択 & 16 & $(/ 43)$ & $37 \%$ \\
& H・I ともに未選択 & 14 & $(/ 43)$ & $33 \%$ \\
\hline
\end{tabular}

*1 写真 $\mathrm{AB}$, 写真 $\mathrm{GH}$, 写真 IJ のうち, 写真 B, H は鮮やかな色彩によっ て多様性が加えられるよう修景された事例であり, 写真 I は本来の 景観において鮮やかな色彩の建築物がみられる事例である。

*2ここでは, 写真 $\mathrm{AB}$ のうち写真 B を選択した被験者数を対象に写真 $\mathrm{GH}$ ・写真 IJでの回答の推移を示している.

*3 写真 B を選択した被験者は，同様に色彩が鮮やかな印象の写真 H と 写真 I を選択する場合が多い。よって, 鮮やかで多様性のある色彩 を嗜好する集団の存在を確認することができる.

表 5 ［質問 II ］・[質問 III］における回答の共通性

\begin{tabular}{|c|c|}
\hline (写真 $\mathrm{AB}, \mathrm{GH}, \mathrm{IJ}$ & \\
\hline 写真 $\mathrm{B}, \mathrm{H}, \mathrm{J}$ のうち 2 つ以上を選択した被験者数 & 33 人 \\
\hline \multicolumn{2}{|l|}{ [質問 III] } \\
\hline 写真 B, H, J のうち 2 つ以上を選択した被験者数 & 17 人 \\
\hline
\end{tabular}

まず，共通イメージ（色彩の落ち着きと統一性のイメージ）につ いて検討する。図 4, 図 5 における写真 $\mathrm{CD}, \mathrm{EF}, \mathrm{GH}, \mathrm{KL}$ の結果をみ ると, 色彩的に落ち着きがあり統一性が高い [本画像] の写真 C, E, G，K が，［質問 II ］，［質問III］ともに高い評価数を得ている．写真 G は，修景後の写真 $\mathrm{H}$ に比べ統一性が低いが，色彩としての落ち着き が評価されたと考えられる.

また, 写真 AB では, [質問 II ] で色味のある写真 B を美しく感じ た被験者が多いが，[質問III] の居住意識では白を基調とした写真A の方が多く選ばれている，さらに，写真 IJ でも，[質問 II ] はほぼ 同数であるが, [質問 III] では自然な色彩で統一性の高い写真 J の方 が高い評価数を示す。つまり, 色彩の鮮やかさと多様性は美しさの 印象を向上させる場合もあるが，基本的に美しさの印象と居住意識 は，ともに落ち着きのある統一された色彩景観について評価が向上 するといえる．

次に，色彩の鮮やかさと多様性のイメージについて検討する。こ うした色彩は［質問 II ］で高評価を得る場合もあり注目すべきであ る.ここでは, 修景の際に色彩の鮮やかさに変化を加えた写真 $A B$, GH，IJ に注目する。

まず, 表 3 に [質問 II ] について写真 AB のうち鮮やかな色彩で修 景された写真 B を選んだ被験者について, 写真 GH, IJ の回答パター ンを示す．これより，[質問 II] で写真 B を選択した被験者のうち $67 \%$ が，同様に鮮やかな色彩のみられる写真 H，写真 I の両方か一方 を選択していることが分かる.特に, 写真B を選択した被験者の $20 \%$ 以上が写真 H と写真 I の両方を選択しており，また $30 \%$ 以上が写真 I を選択している.よって，こうした被験者は鮮やかな色彩への嗜 好性を持つと判断される.この傾向をより明確に示寸ため, [ 質問 II ] に対する回答を数量化し判別分析を行った. 分析では, 写真 $\mathrm{AB}$ のう ち写真 B を選択しており，なおかつ写真 H か写真 I のいずれかを選 択した被験者を「色彩の鮮やかさ・多様性嗜好」, その他の被験者を 共通イメージに基づく「自然基調色嗜好」として分類した．表 4 に 示寸分析結果をみると，判別的中率は $80 \%$ を超えており，それぞれ の分類には妥当性があると考えられる。つまり，写真 B を選んだ被 験者は共通して写真 I と写真 $H$ を選択寸る傾向にあり，この集団が 色彩の鮮やかさと多様性に対する嗜好性を持つことを指摘できる.

表 4 [質問 II］から分類した色彩嗜好に関する判別分析の結果

\begin{tabular}{c|c|c||c}
\hline 質問紙調査の結果による分類 (人) & 判別結果 (人) & 判別的中率 \\
\hline 自然基調色嗜好 & 48 & 37 & \multirow{2}{*}{$81.8 \%$} \\
\hline 色彩の鮮やかさ・多様性嗜好 & 29 & 26 & \\
\hline
\end{tabular}

*1 分類 : (1)色彩の鮮やかさ・多様性嗜好, (2)自然基調色嗜好.

*2 (1) には, 写真 AB のうち写真 B を選択し, さらに写真 $H \cdot I$ の両方もし くは一方を選択した被験者を分類した。.(2)には，その他の被験者を分 類した.

*3 分析では，まず目的変数として，被験者数の合計に占める各分類の被 験者数の割合から，(1)の被験者には 0.38 , (2)の被験者- 0.62 を設定し た. 目的変数の值は写真 $\mathrm{AB}$ の回答を中心に, 写真 $\mathrm{GH} \cdot \mathrm{IJ}$ の回答にも 関連している。

*4 説明変数には写真 $\mathrm{GH}$, 写真 IJ の回答を利用し，写真 H と I を選択 L た場合は 1 , 写真 G と J を選択した場合は 0 として数值化した值を用 いた．以上の目的変数と説明変数を用いて重回帰分析を行い，判別係 数を算出して判別分析を行った.

*5 判別は, 判別得点が正であれば(1)，負であれば(2)という基準により行 った.

*6 判別的中率は, $81.8 \%$ であった。

*7 判別の結果に注目寸ると, 分類は(2)であるが判別結果が(1)に分類され る事例が複数みられる。こうした例は, 写真Iのみを選んだ被験者が 判別の結果(1)に分類される事例が多く，また写真 H と写真 I を選んだ 被験者が(1)に分類される事例もみられた。 
さらに, 表 5 に示すように, 写真 AB, GH, IJ について [質問 II ] で写真 B，H，Iのうち2つ以上を回答した被験者は全て [質問III] でも同様に 2 つ上を回答している. これは, この集団において鮮 やかで多様性のある色彩が美意識と居住意識の両方で高評価を得る ことを示す.

以上から, 全体数に対して(2)に分類される被験者の割合は, [質問 II ] で約 36\%，［質問III］で約 $22 \%$ 程度と低いものの，こうした被 験者は集団として鮮やかで多様性のある色彩を嗜好する傾向にある といえる.

\section{4-2. 色彩景観に対する印象評価}

(i )の分析より, ドイツの都市の色彩景観について被験者が持つ イメージが明らかになった。では, そうした色彩は実際の都市景観 にみられる場合どのように評価されるのであろうか。（ii）の調査よ り, 被験者のドイツの色彩景観に対する印象評価を分析する.

ここでは, 調查結果のプロフィールを分析対象とする (図 6). 色 彩景観をめぐる美しさと居住意識の評価である [質問 II ] および [質 問III] の結果（図 4, 図 5) も参照し, 順に分析を行う.

写真 $\mathrm{AB}$ の結果では, 「鮮やかさ」に関する項目で顕著な評価の差 がみられる。また，「自然基調色」では［22よそよそしい一親しみや すい］の項目で鮮やかな色味のある [修景画像 $]$ 写真 B の評価が [本 画像］写真 Aの評価に近似しており，[(3)冷たいーぬくもりのある] の項目で［修景画像］の評価が高い。「統一性」に関する項目では,
両画像ともに色彩が統一されているものの, 白色で統一された [本 画像］に比べて, 躍動感のある色彩の [修景画像］が相対的な印象 として統一性が低く評価されたと考えられる.[質問III]の居住意識 の評価（図 4）では, [修景画像]の評価数が多く, これは印象評価 の結果に表れた親しみやすさと鮮やかさの評価が影響したと考えら れる.よって, 鮮やかな色彩は, 無彩色と比較して居住意識の評価 を向上させる可能性があるといえる.

写真 CD の結果では,「統一性」と「鮮やかさ」に関する項目で評 価の差が大きい. 外壁色の彩度を上げた［修景画像］写真 D は, よ り鮮やかな印象として評価されており, 特に［99落ち着きのある一 落ち着きのない］の項目で評価の差が大きい，また，彩度を上げた ことで「統一性」に関する項目でも評価が大きく低下している，[8 変化のある一変化のない]の項目で評価の差が小さいのは, [本画像] 写真 C の建築物色彩が緑と赤というコントラストの明確な色彩であ り, 彩度を上げても印象に極端な変化が生じなかったためと考えら れる. [質問 II ], [質問III] の結果をみると, 色彩が落ち着いており, 統一性がある [本画像] を美しいとする評価が多数である.つまり, 景観全体として建築物色彩の彩度が高まり, 鮮やかさが増すことで, 統一性の印象は低下し, 結果として美しさと居住意識の評価も下が ると考えられる.

写真 EFの結果では,「統一性」と「鮮やかさ」に関する項目で評 価の差が顕著である。これは, 白い外壁で統一された［本画像］写 真 E と比較して, [修景画像] 写真 $\mathrm{F}$ は淡い色彩であっても統一性と

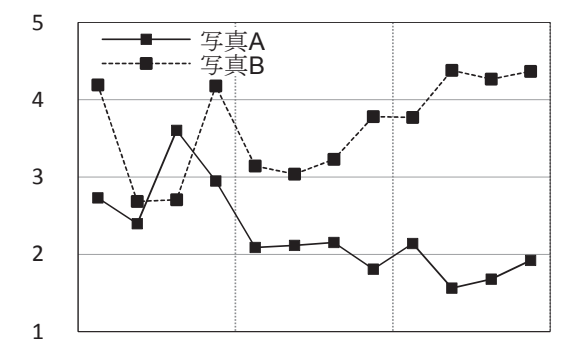

(1) (2) (3) (4) (5) (6) (7) (8) (9) (10) (11) (12)

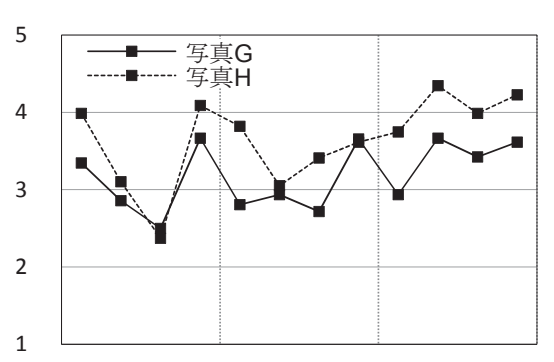

(1) (2) (3) (4) (5) (6) (7) (8) (9) (10) (11) (12)

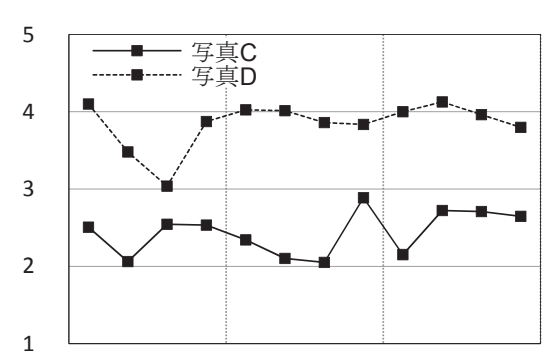

(1) (2) (3) (4) (5) (6) (7) (8) (9) (10) (11) (12)

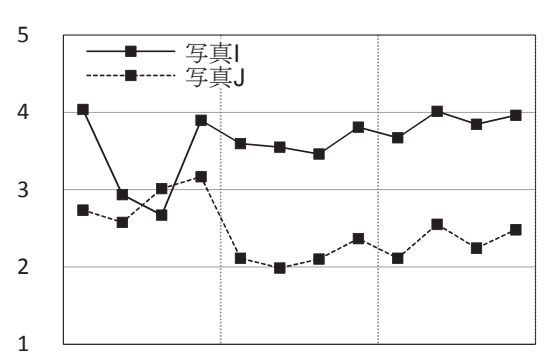

(1) (2) (3) (4) (5) (6) (7) (8) (9) (10) (11) (12)

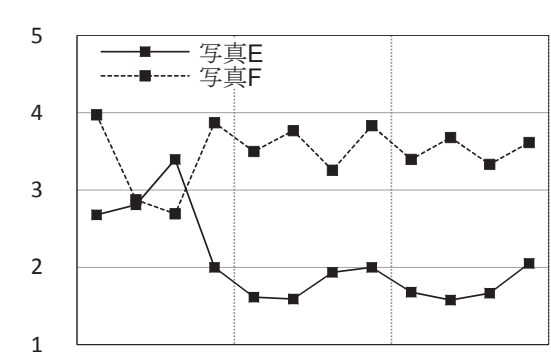

(1) (2) (3) (4) (5) (6) (7) (8) (9) (10) (11) (12)

\begin{tabular}{|c|c|c|c|c|c|c|c|c|c|c|c|}
\hline (1) & (2) & (3) & (4) & (5) & (6) & (7) & (8) & (9) & (10) & (11) & (12) \\
\hline $\begin{array}{l}\text { 人 } \\
\text { 的 } \\
\text { な }\end{array}$ & $\begin{array}{c}\text { L } \\
\text { そ } \\
\text { W上 } \\
\text { そ } \\
\text { L }\end{array}$ & $\begin{array}{l}\text { 冷 } \\
\text { た } \\
\text { W }\end{array}$ & $\begin{array}{l}\text { 現 } \\
\text { 代 } \\
\text { 的 } \\
\text { な }\end{array}$ & 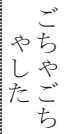 & $\begin{array}{l}\text { ば } \\
5 \\
\text { ば } \\
5 \\
\text { な }\end{array}$ & $\begin{array}{l}\text { 不 } \\
\text { 安 } \\
\text { 定 } \\
\text { な }\end{array}$ & $\begin{array}{l}\text { 変 } \\
\text { 华 } \\
\text { の } \\
\text { あ } \\
\text { る }\end{array}$ & 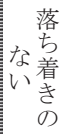 & $\begin{array}{l}\text { に゙ } \\
\text { や゙ } \\
\text { か } \\
\text { な }\end{array}$ & $\begin{array}{l}\text { 刺 } \\
\text { 激 } \\
\text { 的 } \\
\text { な }\end{array}$ & $\begin{array}{l}\text { 華 } \\
\text { や } \\
\text { か } \\
\text { な }\end{array}$ \\
\hline | & | & | & | & 1 & 1 & 1 & | & 1 & | & I & | \\
\hline $\begin{array}{l}\text { 䔳 } \\
\text { な }\end{array}$ & $\begin{array}{c}\text { 親 } \\
\text { い } \\
\text { い } \\
\text { や } \\
\text { 寸 }\end{array}$ & $\begin{array}{c}\text { ぬ } \\
\text { あ } \\
\text { る } \\
\text { り } \\
\text { の }\end{array}$ & $\begin{array}{l}\text { 歴 } \\
\text { 史 } \\
\text { 的 } \\
\text { な }\end{array}$ & 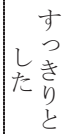 & $\begin{array}{r}\text { ま } \\
\text { あ } \\
\text { る } \\
\text { る } \\
\text { の }\end{array}$ & $\begin{array}{l}\text { 安 } \\
\text { 定 } \\
\text { し } \\
\text { た }\end{array}$ & $\begin{array}{l}\text { 変 } \\
\text { 华 } \\
\text { な } \\
\text { な } \\
\text { 心 }\end{array}$ & $\begin{array}{r}\text { 落 } \\
\text { あ } \\
\text { る 着 } \\
\text { 意 } \\
\text { の }\end{array}$ & $\begin{array}{l}\text { 静 } \\
\text { か } \\
\text { な }\end{array}$ & $\begin{array}{l}\text { 刺 } \\
\text { 激 } \\
\text { の } \\
\text { な } \\
\text { W }\end{array}$ & $\begin{array}{l}\text { 吕 } \\
\text { ん } \\
\text { だ }\end{array}$ \\
\hline
\end{tabular}

*1 プロフィールのうち, 実線は[本画像], 破線は[修景画像]に関する評価 を示す.

*2 調査結果のプロフィールに示す(1)〜12)は, 左に示した各評価項目に該当 する.

*3 評価項目の(1)〜 (4)は「自然基調色」, (5)〜8は「統一性」, (9)〜(12)は「鮮 やかさ」に関係する。

*4 調査結果のプロフィールは, 調査から得られた各評価項目の $1 \sim 5$ 段階に よる評価を平均したものである。その際，自然基調色・統一性に関する 評価項目を 1 , 色彩の鮮やかさ・多様性に関寸る評価項目を 5 として換算 した。つまり, 図の下方ほど, 自然基調色・統一性に関する評価が高く なり, 一方で上方ほど鮮やかさ・多様性に関する評価が高くなると判断 できる.

図 6 印象評価に関する調查結果のプロフィール 
鮮やかさの印象に大きく影響したためと考えられる.また，「自然基 調色」については［2よそよそしい一親しみやすい］の項目で近似 の評価がみられる。[修景画像］に対して親しみの評価が高いのは, 白色で統一された壮麗な印象の［本画像］に対し，修景画像］の色 彩的多様性が日常的に馴染夕深い景観として評価されたことによる と推察される.しかしながら, [質問 II] では美しさに関して大多数 が，統一性の評価が高い［本画像］を回答している。つまり，統一 性の低下は美しさの評価を低下させるといえる.

写真 GH の結果では, プロフィール全体として顕著な評価の差がみ られない点に特徴がある. [修景画像] 写真 H は, [本画像] 写真 G に比べて鮮やかなオレンジ色の外壁面積が大きい，そのため「鮮や かさ」に関する項目で評価に変化があるが，その差は小さい，さら に,「統一性」に関寸る項目でも, [修景画像]の方がオレンジ色で 統一されているにも関わらず評価の変化は小さい.「自然基調色」で は，特に［(3)冷たい一ぬくもりのある］の項目で評価の差がみられ ないことから, 鮮やかな色彩の建築物は部分的に出現する場合でも, 印象評価に強く影響する可能性を指摘できる. [ 質問 II ] でも [本画 像]の回答が多数であることから, 色彩的に統一された景観であっ ても［修景画像］のように鮮やかな色彩の場合には美しさの評価が 下がると考えられる，よって，鮮やかな色彩は，たとえ同系色を並 置しても「統一性」に関する評価は向上せず，結果的に美しさの評 価も下がる. 一方で, 鮮やかな色彩の建築物は連続して立地するよ りも部分的に出現するほうが美しさに関する評価が高いといえる.

写真 IJ の結果では,「統一性」と「鮮やかさ」に関する項目で評 価の差が大きい. これは, [本画像] 写真 I の建築物にみられる高彩 度の赤色が影響したためと考えられる. 特に,「鮮やかさ」に関する 項目と [3(冷たい一ぬくもりのある] の項目での評価は, この影響 によるといえる. また，こうしたアクセントとなる色彩が，[修景画 像］写真 Jのように他の建築物色彩と同化されることで,「統一性」 に関する評価が顕著に変化している.これは写真 $\mathrm{GH}$ と同様に, 部分 的な高彩度の色彩が印象評価に強く影響することを示す。さらに， [(2)よそよそしいー親しみやすい]の項目で評価が近似しているこ とから, アクセントとなる鮮やかな色彩がみられる場合でも, 馴染 みのある景観として評価される傾向にあるといえる. [質問 II ] の美 しさに関する評価はほぼ同数であり，[質問III] では自然基調色で統 一された [修景画像] に評価数が移行している.つまり, 鮮やかな 色彩は, 色彩景観の美しさに関する評価を向上させる可能性がある. その一方で, 自然基調色による統一性のある色彩景観は, 居住環境 としての評価に貢献すると考えられる.

写真 KL の結果では,「統一性」と「鮮やかさ」に関する項目で変 化が大きい. これは, [修景画像] 写真 L が寒色を基調としながらも 色相に変化があり, 躍動感のある印象を与えたためと考えられる. また,「自然基調色」に関する項目では, [本画像] が自然基調色で あり，[修景画像］が寒色であるにも関わらず，[(3)冷たい一ぬくも りのある]の項目で評価に差がみられない, これは, 暖色系の看板 色彩の影響によると推察される。本稿では看板色彩は対象としない ため，この評価の差は有意なデータとして扱わない，よって，[質問 II ］，質問III］ともに［本画像］の評価が高いことから，自然基調 色で統一され落ち着いた色彩景観が美しく評価されるといえる.

\section{4-3. まとめ}

以上の分析から，本稿で目的とした，ドイツの都市の色彩景観に 対する印象評価についてまとめる.

（i ）の分析から，色彩景観のイメージとして，(1)「色彩の落ち着 きと統一性のイメージ」と(2)「色彩の鮮やかさと多様性, 統一性の イメージ」が明らかになった。(1)のイメージは多数の被験者に共通 して確認されたものであり, 色彩景観をめぐる美意識についても高 評価を得るイメージである. よって, (1) は共通イメージ」として 一般化することができる。また，(2)のイメージは被験者のうち部分 的ではあるが，色彩景観をめぐる美意識に強い関係性を示す。よっ て，(2) は一般化されないものの，複数の被験者に共有されたイメー ジとして理解できる，こうしたイメージは，ドイツの色彩景観の特 徽としてあげた 3 要素におおよそ一致する結果であった。

（ii）の分析では，色彩景観に対する被験者の印象評価を検討する ため, 計 12 の評価項目について得られた結果をプロフィールにより 分析した。得られた結果を以下にまとめる.

まず，(1)「共通イメージ」に関して以下の 2 点が確認された

（1）統一性のある色彩景観は美しさの評価を高め, 逆に統一性がそ しくなると評価は低下する。

（2）自然基調色による落ち着いた統一性のある色彩景観は，美観の 点で評価されると同時に，居住環境としても高く評価される。 また，(2)イメージについては以下の 4 点が確認された。

（1）鮮やかな色彩の建築物は美観, および居住意識において評価さ れる可能性がある.

（2）鮮やかな同系色の建築物が連続しても「統一性」に関する評価 は向上せず，結果的に美しさの評価も低下する.

（3）複数の建築物が立地する空間において, 景観全体の建築物の彩 度を上げると，「鮮やかさ」の印象の変化に加えて「統一性」の 印象が低下寸る．結果として美しさの評価も低下寸る.

(4) 鮮やかな色彩の建築物は連続して立地するよりも部分的に出現 することで美しさの評価が向上する.

つまり，ドイツの都市の色彩景観に対する，被験者の美意識に基 づく印象評価は，以下の 3 点に整理することができる.

（1）色彩景観の「統一性」は, 人々の美意識に密接に関係する.

（2）自然基調色は, 美しさや居住環境としての快適さの向上に影響 寸る．自然基調色で統一性のある景観は，美観の点からも安定 して高評価を得る.

（3）比較的高彩度で鮮やかな印象の建築物色彩については, 鮮やか な色彩の建築物が視環境において空間的に大部分を占めず, 部 分的に出現する場合において，美しさに関する評価が向上する.

\section{5. おわりに}

本稿では, ドイツの都市の色彩景観をめぐる日本人の被験者の美 意識に注目し，人々の色彩景観に対寸るイメージと印象評価を明ら かにすることを目的とした，結果として，色彩景観の統一性に対す る評価が再確認された。さらに, 自然基調色に対する美意識と鮮や かな色彩に対する評価の可能性が確認された，前者はドイツを含む 様々な地域の色彩景観にも一般化される可能性がある。後者につい ては，日本国内で騒色と危惧される鮮やかな色彩が，ドイツの事例 では美観の評価を向上させる要因となる点は興味深い。その背景に 
は, 国における文化的な価值観の差異と, それを生み出寸社会文化 的な諸要因が影響していると考えられる.

ある地域の景観を目にしたとき, 人々は景観に関する様々な地理 的情報を想起する。 それは, 国や地域の地理的位置, 気候, さらに は地域のイメージを含む.つまり, 建築物色彩についても, 単なる 色彩としてではなく, 様々な情報のフィルターを通して個人的・集 団的イメージが反映された価值体系として認識される. 例えばドイ ツの景観を目にした場合, 個人的，もしくは社会的に流布したイメ ージに従って色彩景観の印象が想起されるといえよう.

このように, 色彩景観のイメージは, その地域に関する先験的イ メージに影響される。 そのため, 同じ色彩でも日本国内と海外諸国 とでは印象が変化する，ここで考慮すべきは，今回の評価がドイツ の色彩景観に特有の結果か, もしくは他の都市の色彩景観にも一般 化される結果かどうかという点である. 自然基調色をめぐる評価は ドイツやその周辺諸国の都市, さらには日本国内にも共通寸る美意 識であると推察される。 また, 鮮やかで多様性のある色彩景観はド イツを含む様々なヨーロッパ諸都市に共通してみられる.そのため, そうした都市の色彩景観について調查・分析を行い, 本稿の結果の 位置づけを明確に示寸必要がある。さらに, 日本国内の景観につい ても同様の調查・分析を行うことにより，一般的に騒色とみなされ る色彩に対する肯定的な評価を実証できる可能性がある.こうした 視点から, 研究の発展を望むことができると考えられる.

本稿では, 色彩景観の印象に影響する地域の先験的イメージの一 端を考慮し, 調查・分析を試みた。地域の景観イメージは, 景観保 全の施策や観光政策, 産業など地域文化の影響により生み出され, 育まれていく，そうしたイメージ，およびその形成要因を考慮し， 色彩景観に対寸る人々の印象評価をより多角的な視点から検討寸る 必要があると考えられる。

今後の課題として，ドイツ人を対象とした印象評価の調査が考え られる. それによって, 日独の被験者の色彩嗜好や色彩感覚の共通 性，および差異を比較検討することができる．また，色彩景観のイ メージ形成に影響する既述の要因を考慮し, 様々な都市を対象に事 例研究を蓄積する必要がある.

\section{注}

注 1 ) 修景操作による画像を用いた印象評価の調査は, 日本色彩学会誌 vol. 31 (SUPPLEMENT)，pp.152-153 に掲載された「色彩景観からみたドイツの都 市風景」における調查結果に基づく、本稿では，その調査結果をもとに， より詳細な分析を行った。

注 2 ) 本稿投稿時には刊行されていないが, 日本色彩学会誌 34-2（2010 年 6 月号）に掲載予定の「都市の風土色に関する研究一ドイツにおける建築物 色彩の定量的分析をもとに一」において, ドイツの都市の色彩景観の特徴 に関する詳細が述べられている.

注 3 ) 内田（1987）11)では，ドイツの建築物外壁や屋根に頻繁にみられる茶 褐色やレンガ色のことを「大地の色」と称している. 本稿では, そうした 色彩を含め, より幅広く建築に利用された自然環境で採取される岩石や木 材の色彩を指して「自然基調色」という概念を用いることにする.

注 4 ）「マルクト広場」，「商店街（アメニティ・ストリート）」，「木組 み建築」, 「新興住宅地」の分類は, 注 2 々同様, 掲載予定の論文におけ る調査結果に基づく.

\section{参考文献}

1）稲垣卓造: 景観整備を目的とした都市の色彩評価に関する実験的研究, 日 本建築学会計画系論文集 第 451 号, pp. 29-39, 1993.9

2）木多道宏, 鄭在熙, 舟橋國男, 奥俊信, 小浦久子 : 都市景観における視営
的「まとまり」に関する研究, 日本都市計画学会学術研究論文集, 第 31 号, pp. 205-210, 1996. 11

3）木多道宏，奥俊信，舟橋國男，紙野桂人：建物壁面の色彩配列および修 景操作と心理効果との関係一都市景観における色彩の評価構造に関する研 究その 2-, 日本建築学会計画系論文集, 第 516 号, pp. 177-184, 1999.2

4) 稲垣卓造 : 実地における都市の色彩評価に関する研究, 日本建築学会計画 系論文集，第 467 号，pp. 31-37，1995. 1

5) 山本早里, 中山和美, 乾正雄, 槙究: 日欧街並の色彩に関する調查研究 (そ の 5）街並の印象と色彩分布との関係，日本建築学会大会学術講演梗概集 D-1, pp. 377-378, 2000.7

6）山岸明浩, 佐々木博昭 : 建築物における外壁の色彩と心理的効果の関係一 地域計画手法に関する基礎的研究一, 県立新潟女子短期大学研究紀要, 第 40 号, pp. 9-14, 2003.

7）池田圭介：吉祥寺サンロード商店街色彩調査と印象評価, 日本建築学会大 会学術講演梗概集 D-1, pp. 323-324, 2005.7

8）内田順文 : 都市の「風格」についてー場所イメージによる都市の評価の試 み一, 地理学評論, 59-5, pp. 276-290, 1986.5

9）内田順文 : 地名・場所・場所イメージー場所イメージの記号化に関する試 論一, 人文地理, $39-5$, pp. 1-15, 1987. 10

10) Tuan, Y. : SIGN AND METAPHOR, Annals of the Association of American Geographers, Vol.68-3, pp. 363-372, 1978.9

11）内田芳明：風景と都市の美学一南北ヨーロッパの旅から一 朝日選書 1987

（2010年 2 月 10 日原稿受理，2010年 5 月24日採用決定） 